Pedagogik Jurnal Pendidikan, Oktober 2016, Volume 11 Nomor 2, (9-24)

\title{
PENANAMAN SIKAP WIRAUSAHA SISWA PROGRAM TATA BOGA DI SMK NEGERI 3 PALANGKA RAYA
}

\author{
Oleh : Sogi Hermanto *
}

\begin{abstract}
Abstrak
Penelitian ini bertujuan untuk mendapatkan deskripsi tentang Penanaman Sikap Wirausaha Siswa Program Tata Boga Di Sekolah Menengah Kejuruan negeri 3 Palangka Raya, yang dijabarkan menjadi 4 (empat) sub fokus sebagai berikut: (1) untuk mengetahui penanaman sikap wirausaha siswa, (2) untuk mengetahui kondisi wirausaha siswa, (3) untuk mengetahui cara guru dalam menanamkan sikap wirausaha, dan (4) untuk mengetahui faktor pendukung dan faktor kendala yang dihadapi dalam penanaman sikap wirausaha siswa

Penelitian ini menggunakan pendekatan kualitatif dan jenis penelitian studi kasus dengan melibatkan 6 responden (Kepala sekolah, Ketua Program Tata Boga, Guru pengajar kewirausahaa, dan 3 Siswa). Prosedur pengumpulan data menggunakan wawancara, observasi, dokumentasi. Analisis data dengan cara pengumpulan data, reduksi data, penyajian data dan verifikasi atau Penarikan kesimpulan.

Hasil penelitian menunjukkan bahwa penanaman sikap wirausaha Siswa Program Tata Boga Di SMK Negeri 3 Palangka Raya: (1) deskripsi penanaman sikap wirausaha sudah dilakukan sejak berdirinya sekolah SMKN 3 dengan terus mengacu pada visi dan misi, tujuan, serta motto SMKN 3 sikap wira usaha itu selalu ditanamkan. (2) deskripsi kondisi wirausaha siswa sangat bagus karena terbukti di program ini sudah ada 3 wirausaha yang berjalan dengan baik (a) wirausaha Kantin Sehat, (b) Kafetaria kantin, dan (c) Penyewaan alat Perlengkapan Tata Boga. (3) deskripsi cara guru dalam menanamkan sikap wirausaha siswa dengan menerapkan metode pembelajaran, melakukan praktek, mengoptimalkan pemanfaatan sarana prasarana, mengikutsertakan siswa dalam wirausaha, memotivasi siswa. (4) deskripsi factor pendukung dan factor kendala yang dihadapi dalam penanaman sikap wirausaha siswa: (a) factor pendukung yaitu dari guru-guru, orang tua siswa, sarana prasarana, motivasi dan dukungan. (b). factor kendala yaitu siswa kurang berminat, factor biaya, dan latar belakang siswa.
\end{abstract}

\section{Kata Kunci : Penanaman Sikap, Wirausaha, Tata Boga}

\section{PENDAHULUAN}

Penanaman sikap wirausaha kepada para generasi muda terutama bagi siswa tingkat pendidikan SMK memiliki peran strategis dan peran sentral dalam kehidupan dan pembangunan suatu bangsa. Salah satu indikator maju tidaknya suatu negara adalah dilihat dari jumlah wirausahawannya. Ciputra (dalam Tilaar, 2012:11) menyatakan bahwa, suatu negara maju sekurang-kurangnya memiliki $2 \%$ (dua persen) dari jumlah penduduknya sebagai entrepreneur. Jika jumlah wirausahawan suatu negara banyak, maka akan banyak lapangan pekerjaan yang tercipta, sehingga akan berdampak pada semakin berkurangnya jumlah pengangguran. Penanaman sikap wirausaha sangat perlu untuk diadakan guna menambah jumlah wirausahawan dan mengurangi jumlah pengangguran. Selain memberikan bekal ketrampilan, penanaman sikap wirausaha juga dapat digunakan sebagai sarana untuk menanamkan nilai-nilai kewirausahaan. Melalui Penanaman sikap wirausaha pula akan dapat menumbuhkan jiwa wirausaha.

Salah satu tantangan dalam pendidikan nasional dewasa ini ialah bagaimana 
melahirkan manusia-manusia entrepreneur dari lembaga-lembaga pendidikannya, baik pendidikan formal maupun nonformal (Tilaar, 2012: xvi).

Sekolah sangat ideal sebagai tempat melaksanakan penanaman sikap wirausaha, karena wirausaha berkaitan dengan karakter kemandirian, penanaman sikap wirausaha akan melatih siswa menjadi siswa yang mandiri, tidak mudah tergantung pada orang lain dalam menyelesaikan tugas-tugasnya. Penanaman sikap wirausaha memberikan keterampilan-keterampilan berupa teori dan praktik guna mempersiapkan siswa menjadi tenaga-tenaga siap pakai serta memahami dunia usaha dalam kehidupan sehari-hari yang terjadi di lingkungan masyarakat.

Pendidikan merupakan kebutuhan sepanjang hayat Pendidikan sangat penting bagi peningkatan kualitas sumber daya manusia, dengan demikian pendidikan harus diarahkan untuk menghasilkan manusia yang berkualitas dan mampu bersaing di era globalisasi serta memiliki budi pekerti yang luhur. Salah satu tujuan pendidikan adalah menyiapkan peserta didik menjadi anggota masyarakat yang memiliki kemampuan akademik atau profesional yang dapat menerapkan, mengembangkan dan menciptakan ilmu, teknologi dan kesenian. Program pendidikan yang ada dituntut untuk selalu menyediakan sumber daya manusia yang handal dalam rangka menjawab problematika. Pembaharuan dan pengembangan pendidikan harus memperhatikan masalah-masalah dasar yang sedang dihadapi saat ini. Penyelenggaraan pendidikan di Indonesia menganut sistem pendidikan Nasional, meskipun juga merupakan sistem otonomi daerah sebagai konsekuensi logis dari sistem pendidikan nasional tersebut, maka tujuan pendidikan bersifat nasional, yaitu yang terdapat di dalam Undang - Undang Republik Indonesia Nomor : 20 Tahun 2003 tentang Sistem Pendidikan Nasional (Sisdiknas) Pasal 3 yang berbunyi bahwa : "Pendidikan nasional berfungsi mengembangkan kemampuan dan membentuk watak serta peradapan bangsa yang bermartabat dalam rangka mencerdaskan kehidupan bangsa, bertujuan untuk berkembangnya potensi peserta didik agar menjadi manusia yang beriman dan bertaqwa kepada Tuhan Yang Maha Esa , berakhlak mulia, cakap, kreatif, mandiri dan menjadi warga Negara yang demokratis serta bertanggung jawab". (UU. No 20 Tahun 2003:7)

Pendidikan merupakan suatu proses belajar mengajar yang bertujuan untuk mengubah sikap dan tingkah laku manusia dari suatu kondisi tertentu yang masih belum sempurna ke kondisi kesempurnaan sebagaimana yang diharapkan oleh masyarakat sesuai dengan tujuan pendidikan yang terdapat di dalam UndangUndang Nomor 20 Tahun 2003, pendidikan merupakan hal yang mutlak untuk dilakukan oleh setiap warga Negara Indonesia dalam rangka pengembangan diri dan dalam upaya meningkatkan taraf hidup dan kesejahteraan bangsa Indonesia secara keseluruhan.

Sekolah sebagai lembaga pendidikan formal, salah satu fungsinya digunakan untuk sarana pengembangan ilmu pengetahuan yang berkualitas, banyak bergantung pada sekolah di mana siswa menimba ilmu termasuk di SMK Negeri 3 Palangka Raya. Mengingat pentingnya Pendidikan dalam pembangunan ini, maka pemerintah selalu berusaha untuk meningkatkan pendidikan. Fungsi lain dari sekolah adalah sebagai wadah untuk memperoleh, meningkatkan, mempertahankan, mewujudkan kemampuan 
dan merupakan lingkungan yang dapat memberikan pengalaman baru kepada siswa. Menurut para ahli Sekolah adalah tempat dimana kita sebagai seorang pelajar mendapatkan ilmu pengetahuan, dari ilmu pengetahuan maka kita dapat meraih citacita yang di inginkan, proses belajar mengajar membutuhkan seorang guru untuk menjadi pembimbing dalam mengajar. "Guru adalah semua orang yang berwenang dan bertanggung jawab terhadap pendidikan murid - murid, baik secara individual maupun klasikal, baik di sekolah maupun luar sekolah". (Ametembun 1994 :33). Ini berarti bahwa seorang guru, minimal harus memiliki dasar-dasar kompetensi sebagai wewenang dan kemampuan dalam menjalankan tugas. Kompetensi guru merupakan suatu kemampuan yang mutlak dimiliki oleh seorang guru, baik dari segi pengetahuan, keterampilan dan kemampuan serta tanggung jawab terhadap murid-murid yang di asuhnya, sehingga tugasnya sebagai seorang pendidik dapat terlaksana dengan baik.

Untuk mewujudkan kegiatan belajar yang baik dan sesuai dengan tujuan guru merupakan salah satu komponen yang berperan penting. Sehingga dengan demikian guru harus memiliki kompetensi yang baik sebagai guru profesional sehingga kegiatan pembelajaran dapat mencapai sasaran dan tujuan yang tepat. Agar siswa dapat berprestasi maka gurulah orang yang di pandang mampu untuk membantu siswanya dalam meningkatkan kompetensi siswa. Guru harus mampu menyusun program - program yang dapat membangkitkan aktivitas siswa, disamping itu kepala sekolah juga berperan harus mampu bertanggung jawab terhadap kemajuan dan kesejahteraan para guru. Kepala sekolah juga harus memberikan penilaian terhadap kewajiban guru sehingga dengan demikian, kepala sekolah dapat memberikan bantuan kepada mereka demi perbaikan etos kerja guru - guru yang baik di masa mendatang, (Donni Juni Priansa, 2013). Guru yang memahami fungsi dan tugasnya tidak hanya sebatas dinding sekolah saja, tetapi juga sebagai penghubung sekolah dengan masyarakat yang juga memiliki beberapa tugas, menurut Rostiyah dalam Satori Djam'an, (2000:36) mengemukakan bahwa fungsi dan tugas guru profesional adalah: Menyerahkan kebudayaan kepada anak didik berupa kepandaian, kecakapan dan pengalaman-pengalaman. Membentuk kepribadian anak yang harmonis sesuai citacita dan dasar negara kita Pancasila. Menyiapkan anak menjadi warga negara yang baik sesuai dengan Undang-Undang Pendidikan yang merupakan keputusan MPR No. 2 Tahun 1983 Sebagai prantara dalam belajar, Guru adalah sebagai pembimbing untuk membawa anak didik ke arah kedewasaan. Guru memiliki tugas yang beragam yang berimplementasi dalam bentuk pengabdian. Tugas tersebut meliputi bidang profesi, bidang kemanusiaan dan bidang kemasyarakatan. Tugas guru sebagai profesi meliputi mendidik, mengajar dan melatih.

Sekolah atau pendidikan menjadi tempat yang sangat strategis untuk menumbuhkan bakat wirausaha. Beberapa alasan sekolah formal dapat menumbuhkan bakat wirausaha, yaitu: “(1) Sekolah adalah lembaga pendidikan yang sangat dipercaya masyarakat untuk masa depan yang lebih baik, (2) Jaringan sudah ada di seluruh pelosok negeri, (3) Melalui sekolah juga bisa menjangkau dan mempengaruhi keluarga anak didik", (Riant Nugroho, 2009).

Sekolah Menengah Kejuruan merupakan sekolah formal di bawah 
Departemen Pendidikan nasional, mempunyai tujuan antara lain adalah menghasilkan tamatan yang siap memasuki lapangan kerja secara mandiri sebagai wirausaha (entrepreneur). Dengan usia siswa yang rata-rata masih dalam masa yang produktif untuk menerima ilmu pengetahuan dan teknologi termasuk di dalamnya ilmu wirausaha, maka SMK menjadi sangat penting dalam menyiapkan tamatan yang siap berwirausaha. Untuk itu, karakteristik wirausaha di SMK perlu dikondisikan baik melalui jalur kegiatan intrakurikuler, kokurikuler maupun ekstrakurikuler. (http://StrategikPendidikan. Blogspot.com). Sehingga diharapkan dengan kondisi lingkungan yang menerapkan karakteristik wirausaha, siswa menjadi terbiasa untuk menerapkannya dan pada akhirnya akan menjadi karakter kepribadian siswa. Istilah kewirausahaan berasal dari terjemahan "Entrepreneurship", dapat diartikan sebagai "the backbone of economy", yang artinya adalah syaraf pusat perekonomian atau pengendali perekonomian suatu bangsa (Soeharto Wirakusumo, 1997:1). Secara epistimologi, kewirausahaan merupakan suatu nilai yang diperlukan untuk memulai suatu usaha atau suatu proses dalam mengerjakan sesuatu yang baru dan berbeda.Menurut Thomas W Zimmerer 1984, kewirausahaan merupakan penerapan kreativitas dan keinovasian untuk memecahkan permasalahan dan upaya untuk memanfaatkan peluang yang dihadapi sehari-hari. Kewirausahaan merupakan gabungan dari kreativitas, keinovasian dan keberanian menghadapi resiko yang dilakukan dengan cara kerja keras untuk membentuk dan memelihara usaha baru.

Dalam Peraturan Menteri Pendidikan Nasional Nomor 23 tahun 2007, tentang Standar Kompetensi Lulusan Satuan Pendidikan SMK/MAK antara lain bahwa menguasai kompetensi program keahlian dan kewirausahaan baik untuk memenuhi tuntutan dunia kerja maupun untuk mengikuti pendidikan tinggi sesuai dengan kejuruannya. Dari ketentuan peraturan tersebut di atas dapat diambil kesimpulan bahwa SMK mempunyai tujuan agar lulusannya pada akhirnya siap memasuki lapangan kerja dan melanjutkan pendidikan ke jenjang yang lebih tinggi. Dalam konteks siap memasuki lapangan kerja adalah sebagai tenaga kerja tingkat menengah untuk memenuhi kebutuhan lapangan kerja, maupun secara mandiri berwirausaha sehingga dapat menciptakan lapangan kerja. Sesuai dengan Peraturan Menteri Pendidikan Nasional Nomor 22 tahun 2007 tentang Standar Isi, bahwa struktur kurikulum SMK mencakup antara lain mata pelajaran kewirausahaan dengan jumlah 192 jam. Standar Kompetensi Lulusan pada mata pelajaran kewirausahaan adalah (1) mampu mengidentifikasi kegiatan dan peluang usaha dalam kehidupan sehari-hari, terutama yang terjadi di lingkungan masyarakatnya, (2) menerapkan sikap dan perilaku wirausaha dalam kehidupan seharihari di lingkungan masyarakatnya, (3) memahami sendi-sendi kepemimpinan dan mampu menerapkannya dalam kehidupan sehari-hari serta menerapkan perilaku kerja prestatif dalam kehidupannya, (4) mampu merencanakan sekaligus mengelola usaha kecil/mikro dalam bidangnya Pendidikan SMK diselenggarakan dalam bentuk pendidikan sistem ganda. Tetapi kondisi pembelajaran kewirausahaan di SMK yang umumnya masih didominasi pada model keseragaman, yang kurang memperhatikan latar belakang budaya siswa sebagaimana tuntutan KTSP. Proses pendidikan mulai dari perencanaan, pelaksanaan dan evaluasi tidak hanya dilaksanakan oleh satuan pendidikan SMK, akan tetapi juga 
melibatkan dunia usaha dan industri. Beban belajar SMK/MAK meliputi kegiatan pembelajaran tatap muka, praktik di sekolah dan kegiatan kerja praktik di dunia usaha/industri ekuivalen dengan 36 jam pelajaran per minggu. Dalam penyelenggaraan pendidikan di SMK juga terdapat kelembagaan yang dinamakan Unit Produksi. Penyelenggaraan Unit Produksi adalah pembentukan wadah kegiatan produktif di sekolah yang bertujuan untuk membantu meningkatkan kegiatan belajar berproduksi nyata bagi siswa, sehingga dapat berproduksi sesuai standar dunia kerja serta dapat menanamkan jiwa berbisnis, dan sekaligus membantu sumber dana sekolah. Tujuan diadakan unit produksi adalah sebagaimana tercantum dalam Kepmen Dikbud Nomor 0490/U/1992, Pasal 29, ayat (2), yaitu : memberi kesempatan kepada siswa dan guru mengerjakan pekerjaan praktik yang berorientasi pada pasar. Unit Produksi yang sebagai wadah siswa untuk memiliki sikap wirausaha itu melalui Unit produksi tata boga yaitu: Kantin sehat, Kafetaria kantin, Penyewaan perlengkapan tata boga.

Dalam rangka mencapai cita cita hidup, banyak sekali orang yang berlomba - lomba menempuh pendidikan disekolah - sekolah formal. Tetapi kita tidak dapat menutup mata tentang mutu pribadi dari sebagian besar lulusan/ tamatan pendidikan formal pada dewasa ini. Kebanyakan para lulusan/ tamatan pendidikan formal kita begitu selesai studi cenderung untuk berupaya mencari pekerjaan, jarang para tamatan pendidikan formal yang mau, mampu menciptakan dan mengembangkan pekerjaan baik untuk diri sendiri maupun untuk diri orang lain melalui kegiatan kegiatan wirausaha. Sedangkan Wirausaha adalah keberanian, keuletan serta keperkasaan dalam memenuhi kebutuhan serta memecahkan permasalahan hidup dengan kekuatan yang ada pada diri sendiri. (Wasty Soemanto. 1984:42). Ada 6 kekuatan mental yang membangun kepribadian yang kuat yaitu : (1) berkemauan keras, (2) berkeyakinan kuat atas kekuatan pribadi, (3) kejujuran dan tanggung jawab, (4) ketahanan Fisik dan mental, (5) ketekunan dan keuletan untuk bekerja keras, (6) pemikiran yang konstruktif dan kreatif.

Berkaitan dengan uraian pendahuluan tersebut, maka dalam pembahasan masalah peneliti ingin mengungkapkan tentang "Bagaimana penanaman sikap wirausaha Siswa Pada Program Tata Boga Di Sekolah Menengah Kejuruan (SMK) Negeri 3 Palangka Raya". Dengan tujuan penelitian ini adalah : (1) untuk mengetahui sikap wirausaha siswa, (2) untuk mengetahui kondisi wirausaha siswa, (3) untuk mengetahui cara guru dalam menanamkan sikap wirausaha, dan (4) untuk mengetahui faktor pendukung dan faktor kendala yang dihadapi dalam penanaman sikap wirausaha siswa.

\section{METODE PENELITIAN}

Penelitian ini dilakukan bulan April 2015 sampai bulan Juni 2015 menggunakan pendekatan kualitatif dengan rancangan penelitian studi kasus. Bog dan Taylor dalam Margono (2009) menyatakan bahwa penelitian kualitatif adalah prosedur penelitian yang menghasilkan data deskriptif berupa kata - kata tertulis dan lisan dari orang - orang yang berprilaku yang dapat diamati. Dalam hal ini peneliti berusaha melakukan mengungkapkan fakta - fakta atau kegiatan - kegiatan yang sesuai dengan kenyataan yang ada di lapangan dan data - data yang dikumpulkan berupa kata kata,gambar, dokumen pribadi dan 
dokumen resmi lainnya yang mengarahkan pada fokus penelitian.

Lokasi dan letak Penelitian, lokasi penelitian di wilayah kota Palangka Raya, sedangkan letak penelitiannya adalah SMK Negeri 3 Palangka Raya, Jl. RA Kartini No.25 Palangka Raya.

Sumber Data: Data yang dikumpulkan adalah data yang sesuai dengan fokus penelitian yaitu berkaitan dengan penanaman sikap wirausaha siswa pada program tata boga di sekolah menengah kejuruan (SMK) 3 Palangka Raya. (1) data Primer merupakan data utama yang meliputi kata - kata dan tindakan dari orang - orang yang diamati atau diwawancarai (informan) yang berkaitan langsung dengan Penanaman sikap wirausaha siswa pada program tata boga di SMK Negeri 3 Palangka Raya. Data primer diproleh dari: Kepala Sekolah 1 orang, Ketua Paket Keahlian Tata Boga 1 orang, Guru pengajar 1 orang, dan siswa 3 orang. (2) data sekunder diproleh dari Dokumen - dokumen atau foto - foto yang berhubungan dengan Penanaman sikap wirausaha siswa pada program tata boga di SMK Negeri 3 Palangka Raya.

Prosedur Pengumpulan Data: (1) Wawancara dilakukan dengan terstruktur maupun tidak terstruktur, dan dapat dilakukan dengan tatap muka (face to face) maupun dengan menggunakan telepon. (2) Observasi dilakukan melalui cara yang tidak berperan serta (non participant) yaitu peneliti melakukan pengamatan terhadap Penanaman Sikap Wirausaha Siswa Pada Program Tata Boga Di SMK Negeri 3 Palangka Raya. (3) Dokumentasi dilakukan dengan mencari data mengenai hal - hal berupa catatan, transkrip, buku, surat kabar, foto, majalah, notulen rapat, agenda, dan sebagainya merupakan data pelengkap dari pengumpulan metode wawancara dan observasi.

Teknik Analisis Data: dilakukan secara induktif, penelitian kualitatif dimulai dari dedukasi teori, tetapi dimulai dari fakta empiris. (Margono,2009). Milles dan Huberman mengatakan menyajikan dua metode hal pokok proses analisis: Pertama, model analisis mengalir dimana tiga komponen analisis (reduksi data, sajian data, penarikan kesimpulan/verifikasi) dilakukan saling menjalani proses pengumpulan data dan mengalir bersama. Kedua model analisis intraksi, dimana komponen reduksi data dan sajian data dilakukan bersamaan dengan proses pengumpulan data. Setelah data terkumpul, maka tiga komponen analisis (reduksi data, sajian data, penarik kesimpulan) berintraksi.(Margono, 2009).

Langkah-langkah analisis: (1) Pengumpulan data, dilakukan dengan cara pencatatan hasil wawancara dan observasi. Bila jawaban yang diwawancarai setelah dianalisis belum memuaskan maka peneliti melanjutkan pertanyaan lagi, sampai tahap tertentu diperoleh data yang dianggap kredibel. (2) Reduksi data, adalah merangkum, memilih hal - hal yang pokok, memfokuskan pada hal - hal yang penting, dicari tema dan polanya. (3) Penyajian data, penyajian data ini akan memudahkan untuk memahami apa yang terjadi, dan merencanakan kerja selanjutnya berdasarkan apa yang telah dipahami tersebut. Dalam penelitian ini data yang diperoleh disajikan dalam bentuk narasi, gambar, dan skema. (4) Penarikan kesimpulan, analisis data yang dikumpulkan selama pengumpulan data dan sesudah pengumpulan data digunakan untuk menarik suatu kesimpulan, sehingga dapat menggambarkan suatu pola tentang 
peristiwa- peristiwa yang terjadi. Analisis data yang terus menerus dilakukan mempunyai implikasi terhadap pengurangan dan atau penambahan data yang dibutuhkan.

Teknik Keabsahan Data: Untuk menentukankan keabsahan (trustworthiness) data diperlukan teknik pemeriksaan didasarkan atas sejumlah kriteria tertentu. Ada empat kriteria yang digunakan, yaitu derajat kepercayaan (credibility), keterampilan (transferability), ketergantungan (dependability), dan kepastian (confirmability). (Maleong,2010). Berdasarkan kriteria teknik keabsahan data di atas, maka peneliti menggunakan teknik Pemeriksaan Triangulasi. Menurut Denzin dalam Moleong (2010). "Membedakan empat macam triangulasi sebagai teknik pemeriksaan yang memanfaatkan sumber, metode, penyidik, dan teori". Dalam penelitian ini peneliti menggunakan sumber triangulasi. "Triangulasi dengan sumber adalah teknik pemeriksaan keabsahan data yang memanfaatkan sesuatu yang lain diluar data itu hal ini dapat dicapai dengan jalan: (1) Membandingkan data hasil pengamatan (observasi) dengan data hasil wawancara, (2) Membandingkan apa yang dikatakan orang di depan umum dengan data yang dikatakannya secara pribadi,

Membandingkan hasil wawancara dengan isi atau dokumen yang terkait" Triangulasi "teknik" pengumpulan data (bermacammacam cara pada sumber data yang sama). (Sumber: Sugiyono, 2008).

\section{HASIL PENELITIAN}

Deskripsi penanaman sikap wirausaha siswa pada program tata boga di SMK Negeri 3 Palangka Raya

Penanaman sikap wirausaha siswa pada program tata boga di SMK Negeri 3 Palangka Raya sudah ditanamkan sejak adanya sekolah (sejak berdirinya sekolah) tersebut, Mulai dari kepala sekolah yang pertama sampai kepala sekolah yang sekarang, itu terbukti dengan adanya dari Visi dan Misi beserta Tujuan setiap Program Keahlian yang ada di sekolah SMK 3 Palangka Raya. Melihat dengan situasi dan kondisi yang ada pada masa sekarang ini maka sekolah tersebut semakin maju dan selalu menambah sarana dan prasarana di sekolah SMK Negeri 3 Palangka Raya dan adanya keinginan untuk terus berkualitas dalam segi keterampilan agar setelah lulus SMK maka anak - anak bisa menerapkan keterampilannya untuk berwirausaha. Sehingga Kepala sekolah juga selalu mengingatkan akan hal penanaman sikap wirausaha pada warga SMK Negeri 3 Palangka Raya. Karena Sekolah Menengah Kejuruan merupakan sekolah formal di bawah Departemen Pendidikan nasional, mempunyai tujuan antara lain adalah menghasilkan tamatan yang siap memasuki lapangan kerja secara mandiri sebagai wirausaha (entrepreneur). Proses penanaman sikap wirausaha siswa pada program tata boga di SMK Negeri 3 ini dilakukan dengan menerapkan berbagai metode pembelajaran, memotivasi siswa, dan sarana prasarana yang menunjang pembelajaran siswa (yang menunjang praktek). Hasil dari penerapan tersebut bisa kita lihat dari kebiasaan siswa di sekolah dan adanya wirausaha siswa disekolah tersebut. Melihat kondisi dan permasalahan - permasalahan yang ada maka sekolah merasakan perlu adanya selalu dukungan berbentuk motivasi, Sarana prasarana kepada siswa, serta penerapan metode pembelajaran agar sikap wirausaha ini ada pada siswa. Dengan melalui motivasi, Sarana prasarana, Serta penerapan metode pembelajaran yang melibatkan pihak sekolah ( kepala sekolah, guru- guru, siswa) 
dan pihak - pihak terkait lainnya maka Sikap wirausaha di sekolah SMK Negeri 3 Palangka Raya ini bisa tertanam pada diri masing-masing siswa.

Penanaman sikap wirausaha pada siswa di SMK Negeri 3 ini khususnya pada program tata boga semakin hari semakin bagus, karena metode pembelajaran dengan semakin menarik dengan sumber yang beragam sehingga siswa tidak mudah bosan, dengan adanya wirausaha siswa di sekolah maka siswa akan menjadi lebih bersemangat. Wirausaha dilakukan dikaitkan dengan sikap dan perilaku disiplin diri, tanggung jawab, kerja keras, semangat untuk belajar dan menemukan cara kerja yang lebih baik, peduli lingkungan dan lain sebagainya. Dengan demikian warga sekolah harus memahami hal-hal tersebut, kemudian menjadikannya sebagai nilai-nilai kehidupan dalam mewujudkan perilaku keseharian. Jika sikap-sikap tersebut bisa tertanam menjadi nilai kehidupan dan terwujud dalam kehidupan kebiasaan sekolah sehari-hari, maka siswa secara bertahap pada akhirnya akan menjadikan kebiasaan dalam kehidupan kesehariannya. Dengan demikian jika siswa ingin menumbuhkan sikap wirausaha, maka perilaku tersebut harus menjadi bagian dari budaya sekolah. Artinya dalam pengelolaan sumber daya, sekolah harus menerapkan prinsip-prinsip wirausaha. Dan di SMKN3 ini sudah menjadi kebiasaan untuk berwirausaha di sekolah, contohnya mengolah makanan di sekolah berarti menjual produk di sekitar sekolah juga, dan akan menghasilkan uang. Ketika mereka berhasil menjualnya berarti mereka sudah siap untuk berwirausaha. Disamping itu juga guru tidak lepas tangan untuk mengawasi siswa tersebut agar siswa itu tahu untuk jujur, disiplin diri, tanggung jawab, kerja keras, dan ketekunannya, dengan begitu maka sikap wirausaha itu akan lebih terwujud lagi walau pun sejak berdirinya sekolah ini sebenarnya sudah ditanamkan hingga saat ini di SMKN 3 Palangka Raya.

Sikap wirausaha ditanamkan di sekolah ini karena adanya keinginan untuk berkualitas, maju, mempunyai keterampilan. Serta melihat situasi dan kondisi pada masa sekarang ini yang selalu mengutamakan keterampilan dalam segala hal. Untuk itu guru - guru yang ada di SMKN 3 ini selalu memikirkan bagaimana caranya agar siswa mempunyai keterampilan dan sikap untuk berwirausaha. Maka untuk menanamkan sikap wirausaha itu guru selalu memberi dukungan kepada siswa, begitu juga dengan sarana prasarana, dan metode pembelajaran yang menarik. Dengan cara seperti itu maka sikap wirausaha pada siswa sudah terwujud mulai dari kejujuran, kerajinan, ketekunan, serta rasa tanggung jawab.

Penanaman sikap wirausaha siswa pada program tata boga di SMK Negeri 3 palangka Raya telah dirasakan pada siswa, bahwa sikap wirausaha itu sudah tertanam pada diri masing-masing siswa, karena ini terbukti siswa sangat bersemangat dalam mengelola wirausaha kantin sehat yang ada di sekolah, dengan motivasi yang selalu diberikan guru - guru kepada siswa, begitu pula dengan sarana prasarana yang lengkap siswa dapat mengembangkan keterampilannya. Selain itu penanaman sikap wirausaha itu pada awalnya siswa sebelumnya tidak mengetahui tetapi lama kelamaan sikap itu ada pada diri siswa berkat dari bimbingan dan arahan dari guru - guru. Guru selalu memberikan contoh kedisiplinan dan kejujuran kepada siswa untuk diri sendiri dan orang lain dengan memperhatikan norma setempat sebagai makhluk social dan berbudaya, juga 
Pedagogik Jurnal Pendidikan, Oktober 2016, Volume 11 Nomor 2, (9-24)

memperhatikan norma agama yaitu makanan yang halal, toyibah dan barokah

\section{Deskripsi kondisi wirausaha siswa pada program tata boga di SMK Negeri 3 Palangka Raya}

Kondisi wirausaha siswa pada program tata boga ini baik. Karena wirausaha yang selama ini di Tata boga dikelola siswa dengan baik. Melihat kondisi ini maka harus lebih dikembangkan lagi agar tumbuh inovasi - inovasi yang baru lagi sehingga mempunyai peluang usaha yang sangat tinggi. Disamping model pembelajaran kewirausahaan yang masih text-book orientied, ternyata sekarang sudah melaksanakan pembelajaran dengan menggunakan metode ceramah yang divariasikan dengan metode diskusi. Jadi kecendrungan siswa hanya untuk pendengar tidak ada lagi. Sebab pada umumnya diskusi dilakukan pada kelas besar yang didominasi oleh guru dengan siswa, sehingga siswa dan guru bisa membahas yang sedang berkembang di dalam masyarakat, terutama yang berhubungan dengan wirausaha. kondisi wirausaha siswa pada program tata boga ini sudah mampu untuk berwirausaha di sekolah yaitu kantin sehat, kafetaria, serta penyewaan alat perlengkapan tata boga. Semangat siswa untuk wirausaha sangat tinggi, mereka menjual juga selalu jujur, kreatif, bekerja keras, sopan, dan tekun. Begitu pula dengan siswa yang tidak ikut berperan dalam wirausaha ini. Siswa yang tidak berperan dalam 3 jenis wirausaha tersebut juga dapat berwirausaha melalui olahan praktek sehari - hari yang dijual kepada siswa atau guru maupun warga sekitar.

Menurut siswa kondisi wirausaha pada program tata boga ini sangat baik. Mulai dari pembelajaran kewirausahaan yang sekarang metode pembelajarannya sudah bervariasi sehingga siswa mudah untuk memahami secara teori wirausaha tersebut. Begitu juga prakteknya dalam sehari - hari siswa mengadakan praktek dan mengolah makanan sehingga menjual kepada warga sekolah maupun warga sekitar. Sehingga ada juga siswa yang sudah ikut serta berwirausaha di SMKN 3 Palangkaraya yaitu : Kantin Sehat, Kafetaria kantin, Penyewaan alat perlengkapan tata boga, dan yang mengelolanya semua berasal dari siswa Program Tata Boga. Wirausaha tidak hanya ada di Tata Boga melainkan di Program lain juga ada. Tetapi melihat kondisi dan situasi dari pada wirausaha Tata boga dibandingkan dengan wirausaha yang lain yang ada di SMKN3 maka wirausaha ini sangat maju pesat, karena wirausaha ini selalu berkembang hingga ke masyarakat juga sudah mulai tahu akan hal tersebut, guru pengajar yang mengajarkan teori tentang wirausaha sangat bangga pada siswa siswi. Karena apa yang sampaikan mereka mampu untuk mempraktekkannya sehari hari di sekolah dengan adanya wirausaha siswa di SMKN3 ini. Siswa selalu semangat, berani dan mempunyai kemauan kerja keras untuk mengembangkan wirausaha ini.

\section{Deskripsi cara guru dalam menanamkan sikap wirausaha}

Cara yang dilakukan guru dalam menanamkan sikap wirausaha pada siswa. Di SMK Negeri 3 Palangka Raya teknik atau cara yang dilakukan yaitu dengan melakukan (1) Selalu mendukung siswa siswi dengan memotivasi, (2) Melakukan praktek sehari - hari di sekolah lalu menjualnya kepada warga sekolah, (3) Menambah sarana prasarana di sekolah agar siswa lebih berprestasi,

Mengikutsertakan siswa dalam wirausaha 
siswa di sekolah, (5) Menerapkan berbagai metode pembelajaran disekolah.

Ada beberapa tekhnik atau cara yang dilakukan agar tetap atau melaksanakan Penanaman sikap wirausaha siswa pada program tata boga di SMK Negeri 3 Palangka Raya: (1) Penerapan metode Pembelajaran wirausaha disekolah, Cara yang dilakukan di sini yaitu pembelajaran sambil melakukan, jadi guru tidak hanya menjelaskan dengan teori melainkan juga dengan praktek di sekolah , (2) Mengikutsertakan siswa dalam wirausaha siswa disekolah, dengan mengikutsertakan siswa dalam wirausaha program tata boga maka siswa akan lebih memahami tujuan dari wirausaha itu, (3) mendukung dan memotivasi siswa untuk selalu berwirausaha.

Strategi atau cara yang dilakukan sekolah maupun guru dalam penanaman sikap wirausaha siswa yaitu dengan melalui: (1) Praktek sehari hari di sekolah, (2) Dengan motivasi dan dukungan dari guru guru, disini guru harus selalu memotivasi siswa agar mereka tidak jenuh dan tau arah tujuan mengapa mereka melakukan sikap wirausaha itu, (3) Mengikut sertakan siswa dalam wirausaha siswa pada program tata boga, langsung dengan mengikutsertakan siswa dalam wirausaha siswa maka akan terbentuknya sendiri karakter wirausaha tersebut, (4) Serta memasukkan nilai - nilai sikap wirausaha kedalam peraturan sekolah,agar siswa terbiasa untuk menerapkan nilai - nilai sikap wirausaha itu.

Cara guru dalam menanamkan sikap wirausaha yaitu: (1) mengikuti apa yang ada saja seperti mengikutsertakan siswa dalam wirausaha program tata boga, (2) menerapkan berbagai metode pembelajaran sehingga siswa lebih berminat dalam wirausaha sehingga sikap wirausaha itu bisa tertanam pada siswa

Cara guru lain dalam penanaman sikap wirausaha yang dilakukan kepada siswa melalui : (1) Praktek sehari - hari disekolah, (2) Berbagai macam metode pembelajaran, (3) Ikut serta berperan dalam wirausaha program tata boga, (4) Guru selalu memotivasi dan mengarahkan siswa, (5) Dengan memberikan sarana prasarana yang selalu mendukung proses belajar

\section{Deskripsi faktor pendukung dan faktor kendala yang dihadapi dalam penanaman sikap wirausaha siswa pada program tata boga di SMK Negeri 3 Palangka Raya.}

Faktor pendukung dan kendala yang dihadapi penanaman sikap wirausaha siswa pada program tata boga di SMK Negeri 3 Palangka Raya

a. Faktor Pendukung: (1) Faktor pendukung kegiatan - kegiatan yang ada di SMK Negeri 3 Palangkaraya ini datang dari guru- guru, orang tua siswa dalam hal biaya, (2) Sarana prasarana untuk menunjang proses kegiatan kegiatan yang ada di Program Tata Boga dan lain sebagainya, (3) Selalu ada motivasi dan dukungan dari guru guru kepada siswa.

b. Faktor kendala: (1) Ada sebagian siswa kurang berminat untuk berwirausaha tetapi menerapkan sikap wirausaha itu, contohnya Siswa berani mengolah makanan dan menerapkan sikap wirausaha itu di dirinya tetapi siswa tersebut kurang berani dalam hal menjual hasil olahannya, (2) Faktor Biaya yang kurang sehingga siswa kurang berinovatif. Kurangnya biaya dalam praktek wirausaha sehingga siswa kadang tidak bisa praktek wirausaha disekolah, (3) Latar belakang siswa 
yang hanya ikut - ikutan dengan teman saja, siswa seperti ini biasanya guru selalu mendekatkan diri kepada siswa sehingga siswa tersebut mampu merubah pola pikirnya dengan ajakan ajakan atau pun motivasi yang selalu di arahkan guru tersebut, Agar siswa ini mampu untuk menerapkan sikap wirausaha yang di ajarkan gurunya dan sama seperti teman - temannya yang lain.

\section{PEMBAHASAN PENELITIAN}

Penanaman sikap wirausaha siswa pada program tata boga di SMK Negeri 3 Palangka Raya

Penanaman sikap wirausaha siswa pada program tata boga di SMK Negeri 3 Palangka Raya, sudah ditanamkan sejak berdirinya sekolah ini, ini bisa dilihat dari visi dan misi, tujuan, motto SMK Negeri 3 Palangka Raya. Mulai dari berdirinya sekolah ini SMK Negeri 3 Palangka Raya yang sebelumnya bernama Sekolah Kesejahteraan Keluarga Atas (SKKA) masih berstatus swasta.

Pada tahun 1980 SMK Negeri 3 Palangka Raya yang sebelumnya bernama SMKK-1 Palangka Raya berubah nama kemudian menjadi Sekolah Negeri dan berdasarkan SK Menteri Pendidikan dan Kebudayaan Nomor : 036/0/1997 tanggal 7 Maret 1997 nama SMKK-1 Palangka Raya pun berubah menjadi SMK Negeri 3 Palangka Raya. Penanaman sikap wirausaha yang sejak dulu sudah ada, bisa dilihat dari perkembangan yang dilakukan sekolah dalam penanaman sikap wirausaha tersebut melalui visi dan misi sekolah itu. Dan guna melahirkan tamatan yang lebih bermental wirausaha lagi di SMK Negeri 3 ini, maka perlu pembiasaan penerapan wirausaha bagi siswa. Pembiasaan penerapan wirausaha di sekolah dapat ditempuh melaui kegiatan belajar mengajar, penerapan nilai-nilai karakteristis kewirausahaan di sekolah dan praktik berwirausaha. Agar penanaman sikap wirausaha ini lebih baik lagi dari yang sudah ada menjadi lebih baik lagi.

Beberapa alasan sekolah formal dapat menumbuhkan bakat wirausaha, yaitu : "(1). Sekolah adalah lembaga pendidikan yang sangat dipercaya masyarakat untuk masa depan yang lebih baik. (2). Jaringan sudah ada di seluruh pelosok negeri. (3). Melalui sekolah juga bisa menjangkau dan mempengaruhi keluarga anak didik". (Riant Nugroho, 2009).

Dalam Peraturan Menteri Pendidikan Nasional Nomor 23 tahun 2007, tentang Standar Kompetensi Lulusan Satuan Pendidikan SMK/MAK antara lain bahwa menguasai kompetensi program keahlian dan kewirausahaan baik untuk memenuhi tuntutan dunia kerja maupun untuk mengikuti pendidikan tinggi sesuai dengan kejuruannya. Dari ketentuan peraturan tersebut di atas dapat diambil kesimpulan bahwa SMK mempunyai tujuan agar lulusanya pada akhirnya siap memasuki lapangan kerja dan melanjutkan pendidikan ke jenjang yang lebih tinggi. Jadi penanaman sikap wirausaha pada SMK Negeri 3 Palangkaraya ini harus selalu ditanamkan lagi walaupun sudah terlihat ada penanaman itu sehingga keinginan untuk berkualitas dan keterampilan sekolah tersebut semakin terasah terus menerus.

\section{Kondisi wirausaha siswa pada program tata boga di SMK Negeri 3 Palangka Raya}

Kondisi wirausaha siswa pada program tata boga di SMK Negeri 3 Palangka Raya, dapat ditemukan sebagai berikut: Sangat bagus karena terbukti di program ini sudah ada 3 wirausaha yang berjalan dengan baik. Ketiga wirausaha itu adalah (1) Kantin 
Sehat, (2) Kafetaria kantin, dan 3) Penyewaan alat Perlengkapan Tata Boga. Tetapi masih ada sebagian siswa yang belum bisa ikut berperan dalam wirausaha itu. Karena siswa tersebut masih belum dapat mengaplikasikan sikap wirausaha tersebut ke praktek wirausaha sehari - hari yang ada disekolah. Jadi siswa masih textbook oriented yang kecenderungan siswa hanya sebagai pendengar saja. Untuk itu, pendidik tidak boleh hanya text- book oriented, sebab menurut biasanya bercorak generalisasi dan mendorong proses pembelajaran hanya sekedar menjejalkan ide-ide abstrak, sehingga siswa cenderung memorizing not understanding. (Sukarman, 1988).

Agar siswa tersebut ikut berperan dalam wirausaha siswa maupun dalam penanaman sikap wirausaha pada siswa yang biasanya kurang berminat maka guru selalu memotivasi agar menjadi lebih baik lagi, dan kondisi wirausahanya semakin maju lagi. Menurut Galbraith (1967) untuk mempelajari suatu ilmu, seseorang harus cekatan dalam menyimak, memahami dan mengambil keputusan, agar nantinya lebih mampu bertahan hidup.

\section{Cara guru dalam menanamkan sikap wirausaha}

Cara guru dalam Penanaman sikap wirausaha siswa pada program tata boga di SMK Negeri 3 Palangkaraya yaitu sebagai berikut: (1) Menerapkan metode pembelajaran, yang kadang juga guru hanya menyuruh siswa untuk menulis saja, Jadi metode pembelajarannya harus diubah menjadi lebih baik lagi atau dengan kata lain guru harus tegas dalam memilih metode pembelajaran yang digunakan. "Purnomo (2005) ada empat pendekatan pembelajaran kewirausahaan yang bisa dilakukan. Empat pendekatan pembelajaran tersebut adalah
Pendekatan pembelajaran kewirausahaan yang bisa dilakukan adalah: Contextual Teaching and Learning (CTL) Approach, Moral Dilemma Discussion (MDD) Approach, Cooperative Learning Approach (CLA), dan Problem Solving Approach"

(Wina Senjaya, 2008) mengemukakan bahwa strategi pembelajaran adalah suatu kegiatan pembelajaran yang harus dikerjakan guru dan siswa agar tujuan pembelajaran dapat dicapai secara efektif dan efisien. Selanjutnya, dengan mengutip pemikiran J. R David, Wina Senjaya (2008) menyebutkan bahwa dalam strategi pembelajaran terkandung makna perencanaan. Artinya, bahwa strategy (cara) pada dasarnya masih bersifat konseptual tentang keputusan-keputusan yang akan diambil dalam suatu pelaksanaan pembelajaran.

Teknik pembelajaran dapat diatikan sebagai cara yang dilakukan seseorang dalam mengimplementasikan suatu metode secara spesifik. Misalkan, penggunaan metode ceramah pada kelas dengan jumlah siswa yang relatif banyak membutuhkan teknik tersendiri, yang tentunya secara teknis akan berbeda dengan penggunaan metode ceramah pada kelas yang jumlah siswanya terbatas. Demikian pula, dengan penggunaan metode diskusi, perlu digunakan teknik yang berbeda pada kelas yang siswanya tergolong aktif dengan kelas yang siswanya tergolong pasif. Dalam hal ini, guru pun dapat berganti-ganti teknik meskipun dalam koridor metode yang sama (Sudrajat, 2008). (2) Melakukan praktek sehari - hari di sekolah lalu menjualnya kepada warga sekolah maupun warga sekitarnya. Praktik kewirausahaan merupakan suatu kegiatan usaha/bisnis sebagai wahana belajar dan berlatih kewirausahaan khusus bagi siswa SMK. Melalui praktik kewirausahaan siswa dibina 
secara khusus untuk menekuni bidang usaha. Dengan demikian kegiatan usaha/bisnis tersebut merupakan kegiatan usaha yang nyata, direncanakan, disusun dan dilaksanakan seluruhnya oleh guru-guru kewirausahan dan siswa SMK, pelaksanaan praktik kewirausahaan sebagai berikut: (1) Praktik secara Individu merupakan kegiatan usaha yang dilakukan oleh siswa secara individu/perorangan, diprioritaskan kepada siswa tingkat XII dengan pertimbangan telah cukup memilki pengetahuan, keterampilan serta memilki sikap mandiri, (2) Praktik secara Kelompok merupakan kegiatan usaha yang dilakukan secara bersama-sama oleh beberapa siswa tingkat $\mathrm{X}$ dan siswa tingkat XI, (3) Menambah sarana prasarana di sekolah agar siswa lebih berprestasi, (4) Mengikutsertakan siswa dalam wirausaha siswa di sekolah, misalnya dalam pemilihan olahan makanan apa yang akan dijual, maka siswa akan mengungkapkan pendapatnya dengan memberikan alasan agar pendapat mereka kuat dan bisa membuka peluang usaha dan kreatif dalam wirausaha. Contohnya lagi siswa ikut serta dalam wirausaha siswa di sekolah dengan begitu siswa akan lebih mendalaminya, dan (5) Memotivasi siswa agar mereka selalu merasa didukung dan selalu menghasilkan inovasi - inovasi yang terbaru, Motivasi ini sangat berpengaruh pada siswa, karena jika tidak ada motivasi maka siswa tidak akan berprestasi.

"Dimyati (2009:80) menyatakan bahwa terdapat 3 hal utama pada kata motivasi yaitu kebutuhan, dorongan, dan tujuan. Dorongan merupakan suatu kekuatan mental saat menjalakan kegiatan untuk memenuhi tujuan yang sudah di rencanakan. Dorongan yang terfokus pada tujuan itu adalah inti dari motivasi. Kata "tujuan" merupakan suatu hal diinginkan oleh seorang individu”.
Menurut Hamalik (2011:161) suatu motivasi dapat menentukan pada berhasil atau tidaknya proses belajar siswa. Apabila saat belajar tidak diimbangi motivasi akan sangat sulit untuk mencapai titik keberhasilan. Seseorang yang belum memiliki motivasi belajar, tentu tidak akan menjalankan kegiatan belajar dengan serius. Hal ini menandakan bahwa sesuatu yang dikerjakan itu tidak dapat mengacu pada segala kebutuhannya. Sesuatu yang terlihat menarik minat orang lain belum tentu menjadi menarik minat lainnya apabila hal tersebut tidak berhubungan dengan kebutuhannya (Djamarah, tahun 2008:148).

Faktor pendukung dan faktor kendala yang dihadapi dalam penanaman sikap wirausaha siswa pada program tata boga di SMK Negeri 3 Palangka Raya.

Faktor pendukung dan faktor kendala yang dihadapi dalam penanaman sikap wirausaha siswa pada program tata boga di SMK Negeri 3 Palangka Raya yaitu:

1) Faktor Pendukung: (a) Faktor pendukung kegiatan - kegiatan yang ada di SMK Negeri 3 Palangkaraya ini datang dari guru- guru, orang tua siswa, dalam hal biaya, (b) Sarana prasarana untuk menunjang proses kegiatan kegiatan yang ada di Program Tata Boga dan lain sebagainya, (c) Selalu ada motivasi dan dukungan dari guru guru kepada siswa.

2) Faktor kendala: (a) Ada sebagian siswa kurang berminat untuk berwirausaha tetapi siswa menerapkan sikap wirausaha itu, contohnya Siswa berani mengolah makanan dan menerapkan sikap wirausaha itu di dirinya tetapi siswa tersebut kurang berani dalam hal menjual hasil olahannya, (b) Faktor Biaya yang kurang sehingga siswa kurang berinovatif. Kurangnya biaya 
dalam praktek wirausaha sehingga siswa kadang tidak bisa praktek wirausaha disekolah, (c) Latar belakang siswa yang hanya ikut - ikutan dengan teman saja, siswa seperti ini biasanya guru selalu mendekatkan diri kepada siswa sehingga siswa tersebut mampu merubah pola pikirnya dengan ajakan ajakan atau pun motivasi yang selalu di arahkan guru tersebut, agar siswa ini mampu untuk menerapkan sikap wirausaha yang di ajarkan gurunya dan sama seperti teman - temannya yang lain.

Peran motivasi dalam proses pembelajaran, motivasi belajar siswa dapat dianalogikan sebagai bahan bakar untuk menggerakkan mesin motivasi belajar yang memadai akan mendorong siswa berperilaku aktif untuk berprestasi dalam kelas, tetapi motivasi yang terlalu kuat justru dapat berpengaruh negatif terhadap kefektifan usaha belajar siswa. Motivasi adalah suatu proses untuk menggiatkan motif-motif menjadi perbuatan/tingkah laku untuk memenuhi kebutuhan dan mencapai tujuan/keadaan dan kesiapan dalam diri individu yang mendorong tingkah lakunya untuk berbuat sesuatu dalam mencapai tujuan. (Drs. Moh. Uzer Usman : 2000)

\section{SIMPULAN}

1) Penanaman sikap wirausaha siswa pada program tata boga di SMK Negeri 3 Palangka Raya, sudah ada sejak berdirinya sekolah SMK Negeri 3. Karena adanya keinginan untuk berkualitas, maju, mempunyai keterampilan. Serta melihat situasi dan kondisi pada masa sekarang ini yang selalu mengutamakan keterampilan dalam segala hal. Guru - guru SMK Negeri 3 memikirkan caranya agar siswa mempunyai keterampilan dan sikap untuk berwirausaha. Dengan terus mengacu pada visi, misi, tujuan, serta motto SMK Negeri 3 ini maka penanaman sikap wirausaha itu selalu ditanamkan di SMK Negeri 3 Palangka Raya.

2) Kondisi wirausaha siswa pada program tata boga di SMK Negeri 3 Palangka Raya yaitu: Sangat bagus karena terbukti di program ini sudah ada 3 wirausaha yang berjalan dengan baik. Ketiga wirausaha itu adalah (1) Kantin Sehat, (2) Kafetaria kantin, dan (3) Penyewaan alat Perlengkapan Tata Boga.

3) Cara guru dalam menanamkan sikap wirausaha siswa yaitu: (1) Menerapkan metode pembelajaran, (2) Melakukan praktek sehari - hari di sekolah, (3) Menambah sarana prasarana di sekolah agar siswa lebih berprestasi, (4) Mengikutsertakan siswa dalam wirausaha siswa di sekolah, dan (5) Memotivasi siswa.

4) Faktor pendukung dan faktor kendala yang dihadapi dalam penanaman sikap wirausaha siswa pada program tata boga di SMK Negeri 3 Palangka Raya yaitu : (a). Faktor Pendukung : (1) Faktor pendukung kegiatan - kegiatan yang ada di SMK Negeri 3 Palangkaraya ini datang dari guru- guru, orang tua siswa, dalam hal biaya, (2) Sarana prasarana untuk menunjang proses kegiatan kegiatan yang ada di Program Tata Boga dan lain sebagainya, (3) Selalu ada motivasi dan dukungan dari guru guru kepada siswa. (b). Faktor kendala yaitu : (1) Ada sebagian siswa kurang berminat untuk berwirausaha tetapi menerapkan sikap wirausaha itu, contohnya Siswa berani mengolah makanan dan menerapkan sikap wirausaha itu di dirinya tetapi siswa 
tersebut kurang berani dalam hal menjual hasil olahannya, (2) Faktor Biaya yang kurang sehingga siswa kurang berinovatif. Kurangnya biaya dalam praktek wirausaha sehingga siswa kadang tidak bisa praktek wirausaha disekolah, dan (3) Latar belakang siswa yang hanya ikut - ikutan dengan teman saja, siswa seperti ini biasanya guru selalu mendekatkan diri kepada siswa sehingga siswa tersebut mampu merubah pola pikirnya dengan ajakan ajakan atau pun motivasi yang selalu di arahkan guru tersebut, agar siswa ini mampu untuk menerapkan sikap wirausaha yang di ajarkan gurunya dan sama seperti teman - temannya yang lain.

\section{SARAN}

1) Bagi Kepala Sekolah, melihat pada masa sekarang yang dituntut untuk selalu berkualitas dan berketerampilan pihak sekolah SMKNegeri 3 Palangka Raya seharusnya tidak selalu mengacu pada visi dan misi, tujuan serta motto sekolah, melainkan harus mengevaluasi hal tersebut sehingga bisa diperbaharui menjadi lebih baik lagi.

2) Bagi pihak Sekolah, seharusnya wirausaha yang ada di SMK Negeri 3 Palangkaraya, khususnya di Kantin sehat dan Kafetaria seharusnya di buat struktur organisasi wirausaha tersebut secara tertulis agar orang - orang bisa liat dan tahu bagaimana wirausaha di sekolah tersebut.

3) Bagi Guru/ siswa pengelola, melihat kondisi wirausaha yang sangat baik pada program tata boga, hendaknya guru atau pihak sekolah (Siswa pengelolanya) selalu berganti atau bergilir agar siswa yang lain bisa merasakan wirausaha disekolah tersebut diantaranya yaitu: (a) kantin Sehat. (b) kafetaria kantin. (c) penyewaan alat Perlengkapan Tata Boga.

4) Bagi guru, melihat cara guru dalam penanaman sikap wirausaha ini sangat bagus, Akan tetapi potensi atau bakat dan kreativitas anak semuanya tidaklah sama, hendaknya guru membentuk grup anak yang mempunyai minat yang sama.

5) Bagi peserta didik (siswa), yang ada di SMKN 3 diharapkan agar menjaga semua sarana dan prasarana yang ada di program tata boga,sehingga sarana tersebut bisa terpelihara.

6) Bagi Orang tua siswa, diharapkan agar selalu memberikan dukungan kepada sekolah dalam penanaman sikap wirausaha siswa pada program tata boga di SMKNegeri 3 Palangka Raya

\section{DAFTAR PUSTAKA}

Ametebun. 1994. Guru Inspiratif dan Inovatif. Jakarta: Permata Puri Media.

Dimyati. 2009. Belajar dan Pembelajaran. Jakarta: Rineka Cipta

Djamarah. 2008. Psikologi Belajar. Jakarta: Rineka Cipta

Donni Junni Priansa. 2013. Kinerja dan Profesionalisme Guru. Bandung: Alfabeta

Hamalik. 2011. Motivasi. Jakarta: Permata Puri Media

Galbraiht. 1967. The New Industrial State Asigned Book. New York: Library Inc.

Kepmendikbud No 0490/U/1992. Tentang Sekolah Menengah Kejuruan.

Nugroho, Riant. 2009. Sekolah Menengah Kejuruan merupakan sekolah formal. Jakarta:

Bumi Aksara. 
Pedagogik Jurnal Pendidikan, Oktober 2016, Volume 11 Nomor 2, (9-24)

Margono, S. 2009. Metode Penelitian Pendidikan. Jakarta. Rineka Cipta.

Moleong, J. Lexy, 2010. Metodologi Peneitian Kualitatif. Bandung: Remaja Rosdakarya. Purnomo. 2005. Berani Berwirausaha. Jakarta: Gunung Jati.

Tilaar, H.A.R. 2012. Pengembangan Kreativitas dan Entrepreneurship dalam Pendidikan Nasional. Jakarta: PT. Kompas Media Nusantara.

Satori, Djam'an. 2000. Pengawas Sekolah dan Pengelolaan Sekolah: Bandung Diklat Calon Pengawas Sekolah.

Sugiyono, 2005. Memahami Penelitian Kualitatif. Bandung: Alfabeta. 2008. Metodologi Penelitian Administratif. Bandung: Alfabeta.

Sudrajat. 2008. Pengertian Pendekatan, Strategi, Metode, Teknik dan Model Pembelajaran. Bandung: Sinar Baru Algensindo

Suharto Wirakusumo, 1997. Peranan Perguruan Tinggi Dalam Menciptakan Wirausahawirausaha Tangguh. Makalah Seminar Jatinangor BIBI-IKOPIN.

Sukarman. 1988. "Sumbangan Media Massa Khususnya Surat Kabar terhadap Pelajaran Ekonomi pada SMAdi Propinsi DIY". Disertasi. Malang: Perpustakaan UM.

Soemanto, Wasty. 1984. Pendidikan Wirausaha (Sekuncup Ide Profesional). Bina Aksara, Malang.

Undang-Undang RI No 20 Pasal 3 Tahun 2003, Tentang Sistim PendidikanNasional (Undang-Undang Sisdiknas)

Undang-Undang RI No 20 Pasal 7 Tahun 2003. Tentang Sistim Pendidikan Nasional. Jakarta: PT Restindo Mediatma.1

Yin, Robert, K. 2009. Studi Kasus Desain dan Metode. Jakarta: Raja Grafindo Persada.

Wina Senjaya. 2008. Strategi Pembelajaran Berorientasi Standar Proses Pendidikan. Jakarta: Kencana Prenada Media

Zimmerer W, Thomas. Et. Al. 1996. Entrepreneurship and The New Venture Formation, New Jersey: Prentice Hall Inc 